\title{
Pre-sprouted seedlings production methods through buds or mini-stems: Emergence and initial development of sugarcane cultivars
}

\author{
Métodos de produção de mudas pré-brotadas via gemas ou minitoletes: \\ Emergência e desenvolvimento inicial de cultivares de cana-de-açúcar
}

\author{
André MAY'; Nilza Patrícia RAMOS ${ }^{2}$; Michelli de Souza dos SANTOS 3 ; \\ Evandro Henrique Figueiredo Moura da SILVA ${ }^{4}$; Paulo ROSSI ${ }^{5}$; Ronaldo da Silva VIANA ${ }^{6}$ \\ ${ }^{1}$ Pesquisador, Embrapa Meio Ambiente, SP 340, km 127,5, Bairro Tanquinho Velho, CEP: 13820-000, Jaguariúna, SP, Brasil. \\ Email: andre.may@embrapa.br *Autor para correspondência \\ ${ }^{2}$ Pesquisador da Embrapa Meio Ambiente. Email: nilza.ramos@embrapa.br \\ ${ }^{3}$ Bolsista de Pós-Doutorado, CAPES, Embrapa Meio Ambiente. Email: michellisantos30@hotmail.com \\ ${ }^{4}$ Mestrando em Engenharia de Sistemas Agrícolas, ESALQ/USP, Email: ehfmsilva@usp.br \\ ${ }^{5}$ Técnico Agrícola, Embrapa Meio Ambiente. Email: paulo.rossi@embrapa.br \\ ${ }^{6}$ Professor Assistente Doutor, Faculdades de Ciências Agrárias e Tecnológicas, UNESP, Dracena/SP. Email:
} ronaldo@dracena.unesp.br

Recebido em: 01-09-2017; Aceito em: 20-07-2018

\begin{abstract}
This study evaluates the emergence and initial development of sugarcane cultivars with different bud sizes, based on the system of pre-sprouted seedlings (PSS). Early sugarcane cultivars (RB966928, RB855156 and IACSP911099) were evaluated. These evaluations comprised three positions of the sugarcane stem (tip, middle and base) and four types of sugarcane propagules (mini-stem and 3 bud sizes with different diameters: $22 \mathrm{~mm}(1), 29 \mathrm{~mm}$ (2) and $35 \mathrm{~mm}(3)$ ). Three trials were performed, each with a different cultivar. The experimental design for each cultivar was a randomized block in a $3 \times 4$ factorial scheme (stem position $\mathrm{x}$ propagule size (vegetative material)) with 4 replicates. Emergence was evaluated daily, and from these evaluations the emergence speed index (ESI) was calculated. Plant height, shoot dry mass and root dry mass were also assessed. Data were submitted to analysis of variance with interaction, and the Tukey test was applied. When simple variable transformations were not enough to meet the assumptions of normality and homoscedasticity, the non-parametric Friedman test was used. ESI indicated that the best type of propagule was the mini-stem, and for cultivars IACSP91-1099 and RB855156 the best performing position was the tip. The Friedman test indicated significance of the causes of variation related to propagule size and stem position for shoot dry mass in all evaluated cultivars. In addition, the test indicated significant variation of root dry mass for cultivars IAC91-1099 and RB966928 between propagule sizes and the stem positions. The height of cultivar IACSP91-1099 showed interaction between the different propagule sizes and stem positions. The greatest increase of height in sugarcane seedlings occurred for the mini-stem propagule and tip position. Cultivars RB855156 and RB966928 also showed interaction between the different propagule sizes and stem positions. Cultivar RB855156 showed the highest plant height with the mini-stem propagule at the tip position, however it did not differ statistically from the propagule with size 3 at the tip and middle positions. The mini-stem and the bud with size 3, removed from the tip of the stem, are the best alternatives for seedling production.
\end{abstract}

Additional keywords: germination; PSS, Saccharum spp; vegetative propagation.

\section{Resumo}

O objetivo desse estudo foi avaliar a emergência e desenvolvimento inicial de diferentes tamanhos de gemas de cultivares de cana-de-açúcar, comparando ao sistema de mudas pré-brotadas (MPB). Foram avaliadas cultivares de ciclo precoce de cana-de-açúcar (RB966928, RB855156 e IACSP91-1099), em três posições do colmo da cana (ponta, meio e base) e quatro tipos de propágulos de cana-de-açúcar (rebolo ou minitolete e 3 tamanhos de gemas com diferentes de diâmetro $22 \mathrm{~mm}$ (1), $29 \mathrm{~mm}$ (2) e $35 \mathrm{~mm}$ (3)). Foram realizados três ensaios cada um com uma cultivar diferente. O delineamento experimental para cada cultivar foi 0 de blocos ao acaso em esquema fatorial $3 \times 4$ (posição do colmo $x$ tamanho do propágulo (material vegetativo) com 4 repetições. Foram realizadas avaliações de emergência diária, e a partir de tais avaliações foram calculados o índice de velocidade de emergência (ESI). Também foram avaliadas as variáveis altura das plantas, a massa seca da parte aérea e a massa seca de raízes. Os dados obtidos foram submetidos a análise de variância (ANOVA) com desdobramento de interação e foi aplicado o teste de Tukey. Quando simples transformações de variáveis não foram suficientes para garantir os pressupostos de normalidade e homocedasticidade foi utilizado o teste não-paramétrico de Friedman. As análises de ESI indicaram que o melhor tipo de propágulo foi o rebolo e para as cultivares 
IACSP91-1099 e RB855156 a posição com melhor desempenho foi a ponta. O teste de Friedman indicou significância das causas de variação relacionadas aos tamanhos de propágulos e as posições do colmo relativas à variável massa seca da parte aérea, em todas as cultivares avaliadas, e ainda que existiu variação significativa da massa seca das raízes para as cultivares IAC91-1099 e RB966928 entre os tamanhos dos propágulos e as posições do colmo. A variável altura da cultivar IACSP91-1099 apresentou interação entre os diferentes tamanhos dos propágulos e as posições do colmo. O maior incremento de altura nas mudas de cana aconteceu no propágulo de tamanho rebolo e a posição do colmo ponta. As cultivares RB855156 e RB966928 também apresentaram interação entre os diferentes tamanhos dos propágulos e as posições do colmo. A cultivar RB855156 apresentou a maior altura de planta quando o propágulo foi o rebolo na posição ponta, contudo não diferiu estatisticamente do propágulo de tamanho 3 na posição ponta e meio. O rebolo e o tamanho de gema 3 retirados da posição ponta do colmo são as melhores alternativas para a produção de mudas.

Palavras-chave adicionais: germinação; MPB; propagação vegetativa; Saccharum spp.

\section{Introduction}

Sugarcane stands out as the main crop of the production chain of biofuels, sugar, fertilizers and other products of the so-called green chemistry in Brazil (Leal et al., 2013). According to the National Supply Company (CONAB, 2017), the sugarcane area in Brazil for the 2016/17 harvest was approximately 9 million hectares, which produced 34.6 million tons of sugar, 11.7 billion liters of anhydrous ethanol and 16.7 billion liters of hydrated ethanol.

Ethanol is known worldwide as a strategic option in renewable energy generation. Eggert \& Greaker (2014) state that, in addition to Brazil, the US and some European countries have introduced policies to support its generation. According to these authors, such policies also comprise the production of secondgeneration (2G) ethanol, obtained from cellulose. The generation of $2 \mathrm{G}$ ethanol, according to the Sugarcane Technology Center (CTC, 2015), could double the current production of biofuel, being able to integrate into the sugar and alcohol sector in their respective production units. According to Marin (2014), ethanol produced from sugarcane is an important generator of foreign exchange for the country. The destinations of this product are South Korea (19.9\%), the United States (13.9\%) and Japan (13.8\%).

Based on the importance of this crop for the country, some significant aspects such as guaranteeing the yield potential of sugarcane fields gain great relevance. The large competitive advantage of the sugarcane sector is mainly a result of agricultural innovations, such as varietal improvement, mechanization of harvesting and planting, and adoption of agricultural input technologies. Notwithstanding, crop installation practices, mainly in relation to the production of sugarcane seedlings, did not follow this evolutionary scenario.

One of the most current and efficient forms of planting and reforestation of sugarcane fields is through pre-sprouted seedlings (PSS). The evolution of this technique can be rescued by the hypothesis raised by Dillewijn (1952), who considered that a small volume of tissue, with a single-root primordium adhered, is enough to guarantee the germination of sugarcane. Years later, the studies demonstrated that sugarcane stem internodes could be eliminated, using only the individualized buds for commercial planting. This improvement in the PSS system can save around 80 to $90 \%$ in terms of plant material used for seedling production compared to conventional mechanized planting system (Landell et al., 2012).

Thus, as an evolution of the PSS technology proposed by the Agronomic Institute of Campinas (IAC), which considers the production of pre-sprouted seedlings of sugarcane from the rooting of mini-stems, the present research proposes the use of individualized buds of sugarcane for the production of presprouted seedlings. The other structures contained in a mini-stem are not needed, that is, only the individualized bud, intact with part of the root zone (structure contained around the bud where the root primordia of the future seedling are), is kept.

A factor that also influences sugarcane sprouting is the bud position on the stem. According to Segato et al. (2006), within the same genotype, the sprouting ability is altered as a function of plant age and the part where the bud is positioned on the stem.

Therefore, the present study evaluates the emergence and initial development of sugarcane cultivars obtained from different sizes of sugarcane propagules, with buds removed from different positions on the stem. The results are compared to the conventional system for pre-sprouted seedlings obtention via mini-stems.

\section{Material and methods}

The experiment was conducted in 2016, in a greenhouse located in the experimental area of Embrapa Meio Ambiente, in Jaguariúna/SP. During the experimental period, the average temperature inside the greenhouse was $29.7^{\circ} \mathrm{C}$, and the mean minimum and maximum temperatures were 25 and $33^{\circ} \mathrm{C}$. The mean minimum and maximum relative air humidity were 16.3 and $62 \%$.

Three trials were performed, each using a sugarcane cultivar (RB966928, RB855156 and IACSP91-1099). The experimental design was a randomized complete block design in a $3 \times 4$ factorial scheme: three positions on the sugarcane stem (tip, middle and base), from which the vegetative material 
(bud) was taken $\mathrm{x}$ four types of propagules (vegetative material) of sugarcane (mini-stem and three sizes of propagules, with one bud each), with 4 replicates. Ten vegetative structures were used in each replicate.

The propagative material used for the production of seedlings was removed from the sugarcane stem. The stem was classified into three parts: the tip, the middle and the base. Of these three parts, propagules of different diameters were extracted. These propagules consisted of an intact bud per internode, with a small variable part of the mini-stem on the sides. The propagules had three different diameters: $22 \mathrm{~mm} \mathrm{(1),} 29 \mathrm{~mm} \mathrm{(2)} \mathrm{and} 35 \mathrm{~mm}$ (3). These propagules were removed with a saw cup, which consists of a tool used with a drill to perform cylindrical cuts, presenting cylindrical dimensions according to each diameter (22 mm, $29 \mathrm{~mm}$ and $35 \mathrm{~mm}$ ). Propagule thickness (a bud plus a small part of the mini-stem) was constant, set at $8 \mathrm{~mm}$, removed from the stem with the aid of a small chisel.

The propagation structures were conditioned, for emergence and growth, in plastic trays containing a layer of draining material (gravel) and a layer of medium sand in the bottom, covering the propagules completely. A plastic tray with perforated bottom was used for each experimental plot. Microsprinkler irrigation was selected as the irrigation method.

The parameter used to evaluate the daily emergence of buds contained in the propagules during the 34 days of the trials was the emergence rate index (ERI). ERI was calculated with daily data of the number of emerged seedlings, using the formula proposed by Maguire (1962):

$\mathrm{ERI}=(\mathrm{G} 1 / \mathrm{N} 1)+(\mathrm{G} 2 / \mathrm{N} 2)+\ldots+(\mathrm{Gn} / \mathrm{Nn})$,

Wherein: E.R.I. = emergence rate index; $G=$ number of normal seedlings computed in the counts; $\mathrm{N}=$ number of days from sowing to the $1^{\text {st }}, 2^{\text {nd }} \ldots \mathrm{n}^{\text {th }}$ evaluation

The final evaluations were performed 34 days after planting, and the following measures were taken: final emergence percentage, plant height (measured from the sand surface to the last developed ligule in the sugarcane seedling), shoot dry mass per plant and root dry mass per plant.

Data were submitted to analysis of variance (ANOVA) with interaction, and the Tukey test was applied to separate means between treatments. The variables ERI, for cultivar RB966928, and root dry mass (RDM), for cultivar RB855156, were square-root transformed to meet the assumptions of normality and homoscedasticity. When simple variable transformations were not enough to meet the assumptions of normality and homoscedasticity, the non-parametric Friedman test was used. Subsequently, the medians were compared by the LSD test in its non-parametric form. The level of significance was maintained at 5\% probability. Thus, the Friedman test was applied to the variables: shoot dry mass (SDM), for all cultivars; height, for cultivars RB966928 and RB855156; RDM, for cultivars IACSP91-1099 and RB966928.

\section{Results}

In the trials with different-sized propagules of cultivars IACSP91-1099, RB855156 and RB966928, there was interaction of sugarcane stem positions for the variable emergence speed index (ERI) (Table 1).

Figure 1 shows the performance of sugarcane cultivars regarding the emergence rate index, propagule size and bud position on the stem. The best performing type of propagule was the minis tem. For cultivars IACSP91-1099 and RB855156, the tip position showed the highest performance.

Table 1 - Analysis of variance performed for emergence speed index (ESI) of the sugarcane seedlings originated from the different size of propagules and sugarcane stalks.

\begin{tabular}{|c|c|c|c|c|}
\hline \multirow{3}{*}{\multicolumn{2}{|c|}{ Causes of variation Degrees of freedom }} & \multicolumn{3}{|c|}{ Mean Square } \\
\hline & & \multicolumn{3}{|c|}{ Sugarcane cultivar } \\
\hline & & IACSP91-1099 & RB855156 & RB966928 \\
\hline Block & 3 & $2.26^{*}$ & $4.56^{*}$ & $0.23^{*}$ \\
\hline Stem & 2 & $73.74^{*}$ & $480.31^{*}$ & $0.05^{\mathrm{NS}}$ \\
\hline Bud & 3 & $27.12^{*}$ & $90.62^{*}$ & $16.93^{*}$ \\
\hline Stem $\times$ Bud & 6 & $14.03^{*}$ & $32.83^{*}$ & $0.38^{*}$ \\
\hline Residue & 33 & $2.46^{*}$ & $4.20^{*}$ & $0.12^{*}$ \\
\hline CV (\%) & & 32.63 & 28.00 & 17.67 \\
\hline
\end{tabular}

${ }^{*}$ significant $(p<0.05)$; ns $=$ not significant $(p>0,05) ; C V$ - coefficient of variation. 


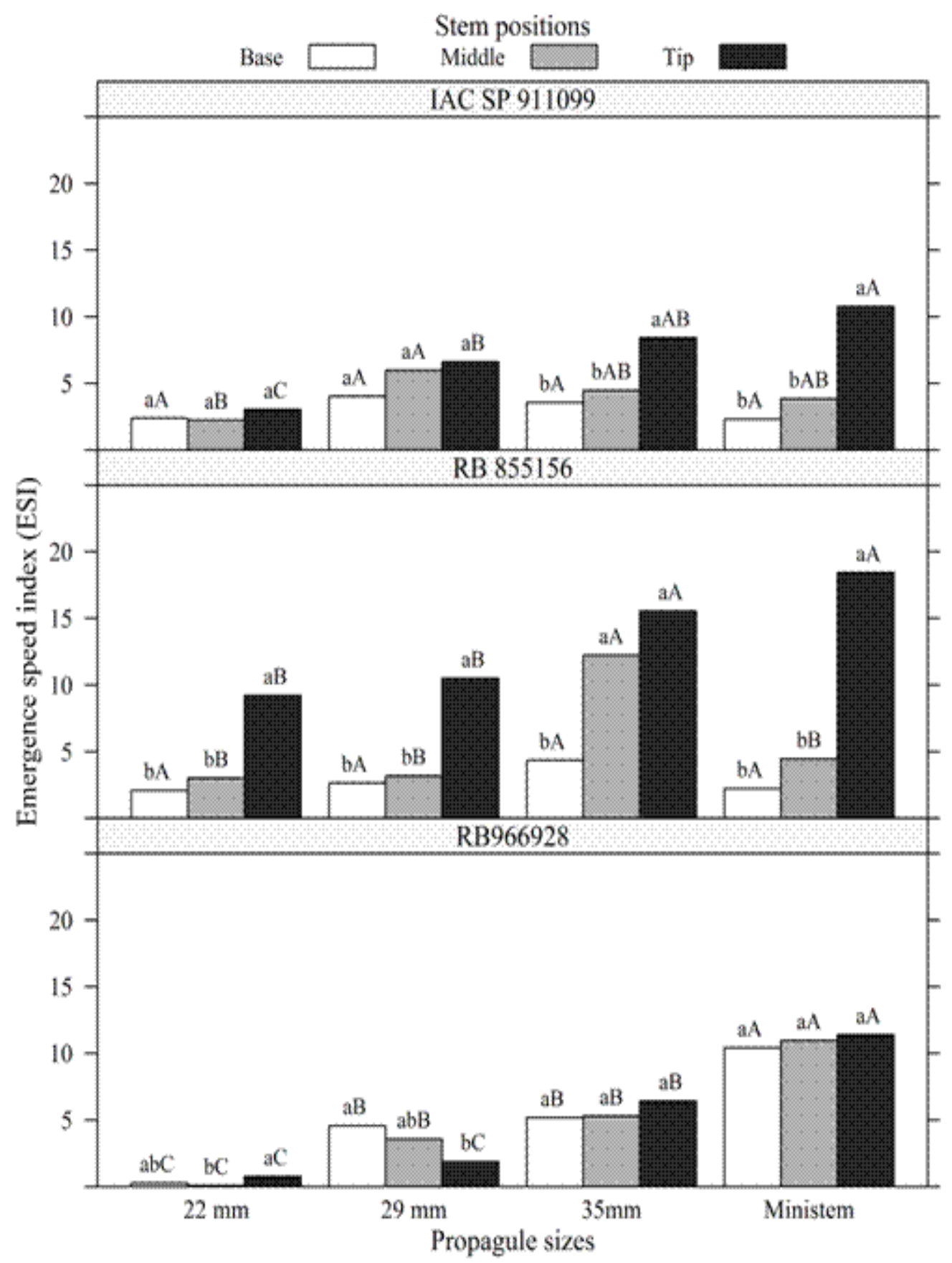

Figure 1 - Emergence speed index (ESI) in the cultivars IACSP91-1099 RB855156 and RB966928 originated from the different size of propagules $(22 \mathrm{~mm}, 29 \mathrm{~mm}$ and $35 \mathrm{~mm}$ ) and sugarcane stalks (Mini-stem). (Means followed by the same lowercase letter do not differ by Tukey test $(p>0.05)$ between the positions of the stem for the same type of vegetative material; Means followed by the same uppercase letter do not differ by Tukey test $(p>$ 0.05), it comparing the same position of the stem in each type of vegetative material).

The sugarcane cultivars used in this study showed different emergence rates according to the propagule size and stem position. Cultivar IACSP911099 had the highest emergence rate, of approximately 20 days for treatments with propagule with size 3 and tip as stem position. Cultivar RB855156 pre- sented better performance for mini-stem propagule and tip as stem position. Cultivar RB966928 reached the highest emergence rates for mini-stem propagule at all stem positions studied. The emergence rate for the mini-stem propagule and tip stem position reached almost $80 \%$ in less than 15 days (Figure 2 ). 


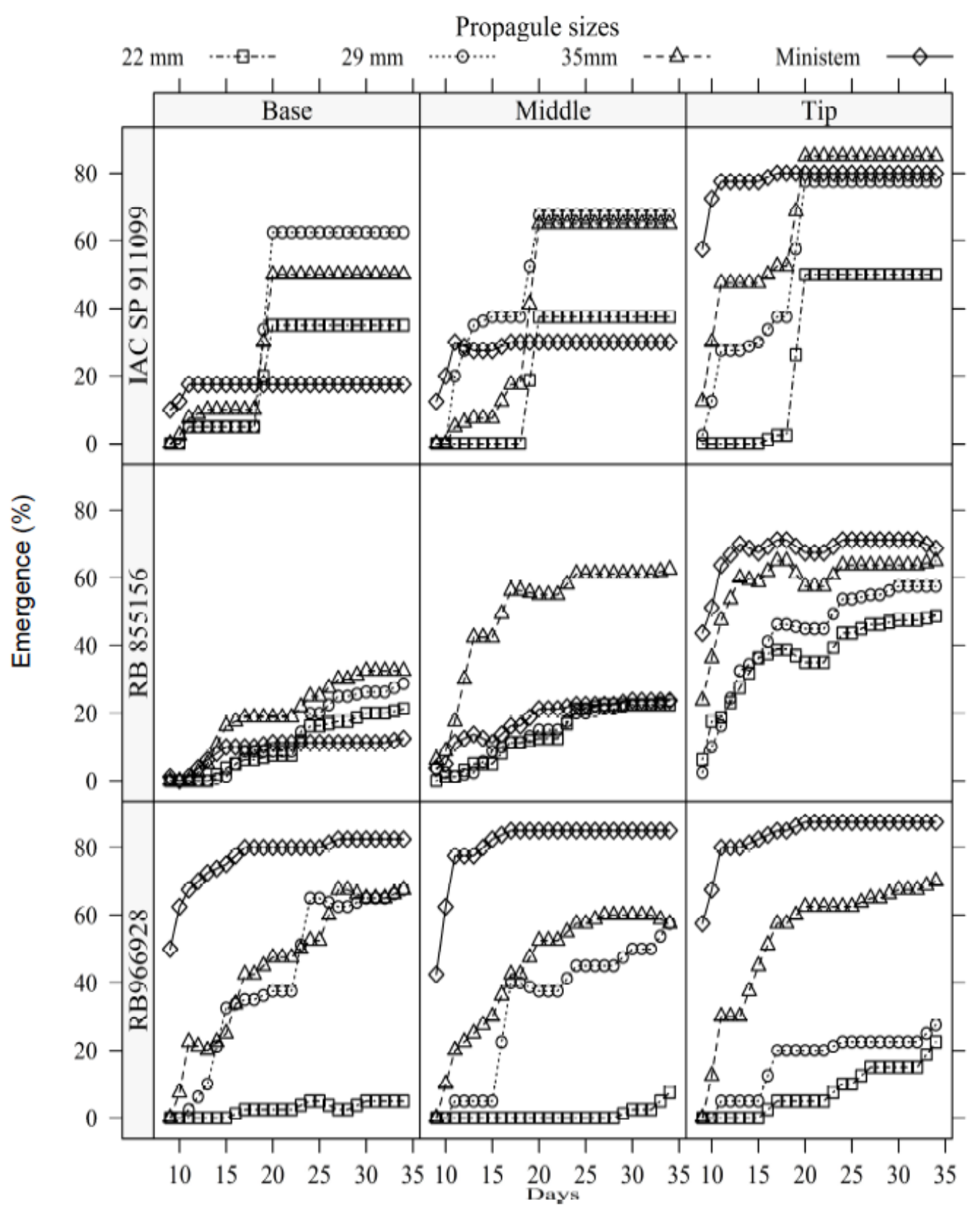

Figure 2 - Percentage of emergence in cultivars IACSP91-1099, RB855156 and RB966928 originated from the different size of propagules (22 mm, $29 \mathrm{~mm}$ e $35 \mathrm{~mm}$ ) and sugarcane stalks (Mini-stems) over time.

The Friedman test indicated that there were significant causes of variation related to the propagule sizes and stem positions, for the variable shoot dry mass, in all cultivars evaluated (Table 2). In all three cultivars studied, the highest dry mass accumulation was obtained in seedlings with mini-stem propagule and tip stem position. For cultivar RB966928, specifically, there was no significant difference between mini-stem propagules and stem positions.

The Friedman test showed that there was a significant variation of root dry mass for cultivars IAC91-1099 and RB966928 between propagule sizes and stem positions. Cultivar IAC91-1099 showed the highest root biomass accumulation with mini-stem propagule at the middle stem position. However, it did not differ statistically neither from the treatments with mini-stem propagules at the base and tip positions, nor from the treatments with propagule size 3 at the base and tip positions. The analysis of variance indicated interaction between the causes of variation propagule size and stem position for the variable root dry mass in cultivar RB855156. In the unfolding of the interaction between propagule size and stem position, root dry mass accumulation was shown to be favored by the mini-stem propagule size at the tip of the stem, differing statistically from the other positions. However, at the base and middle stem positions, the propagule with the highest root dry mass accumulation was that with size 3 (Figure 3). 
Table 2 - Shoot dry mass of cultivars IACSP91-1099, RB855156 and RB966928 originated from the different size of propagules and sugarcane stalk positions.

\begin{tabular}{lccc}
\hline \multirow{2}{*}{ PropagulesiCultivar } & IACSP91-1099 & RB855156 & RB966928 \\
\cline { 2 - 4 } & & $\left(\mathrm{g} \mathrm{plant} \mathrm{-}^{-1}\right)$ & \\
\hline Base, $29 \mathrm{~mm}$ & $17.5 \mathrm{de}$ & $22.0 \mathrm{bcd}$ & $27.0 \mathrm{bc}$ \\
Base, $35 \mathrm{~mm}$ & $20.0 \mathrm{cde}$ & $33.0 \mathrm{ab}$ & $32.0 \mathrm{~b}$ \\
Base, $22 \mathrm{~mm}$ & $20.5 \mathrm{cde}$ & $12.5 \mathrm{~cd}$ & $13.5 \mathrm{ef}$ \\
Base, mini-stem & $36.0 \mathrm{ab}$ & $25.5 \mathrm{bcd}$ & $44.0 \mathrm{a}$ \\
Middle $29 \mathrm{~mm}$ & $29.0 \mathrm{bcd}$ & $28.0 \mathrm{bcd}$ & $20.0 \mathrm{cde}$ \\
Middle, $35 \mathrm{~mm}$ & $29.0 \mathrm{bcd}$ & $34.0 \mathrm{ab}$ & $30.0 \mathrm{~b}$ \\
Middle, $22 \mathrm{~mm}$ & $11.5 \mathrm{e}$ & $15.5 \mathrm{~cd}$ & $6.0 \mathrm{f}$ \\
Middle, mini-stem & $24.0 \mathrm{bcde}$ & $21.0 \mathrm{bcd}$ & $44.0 \mathrm{a}$ \\
Tip, $29 \mathrm{~mm}$ & $32.0 \mathrm{bcd}$ & $33.0 \mathrm{ab}$ & $16.0 \mathrm{de}$ \\
Tip, $35 \mathrm{~mm}$ & $33.0 \mathrm{bc}$ & $29.0 \mathrm{bc}$ & $24.0 \mathrm{bcd}$ \\
Tip, $22 \mathrm{~mm}$ & $11.5 \mathrm{e}$ & $11.5 \mathrm{~d}$ & $11.5 \mathrm{ef}$ \\
Tip, mini-stem & $48.0 \mathrm{a}$ & $47.0 \mathrm{a}$ & $44.0 \mathrm{a}$ \\
\hline
\end{tabular}

Means followed by the same letter in the same column do not differ by Tukey test $(p>0.05)$.

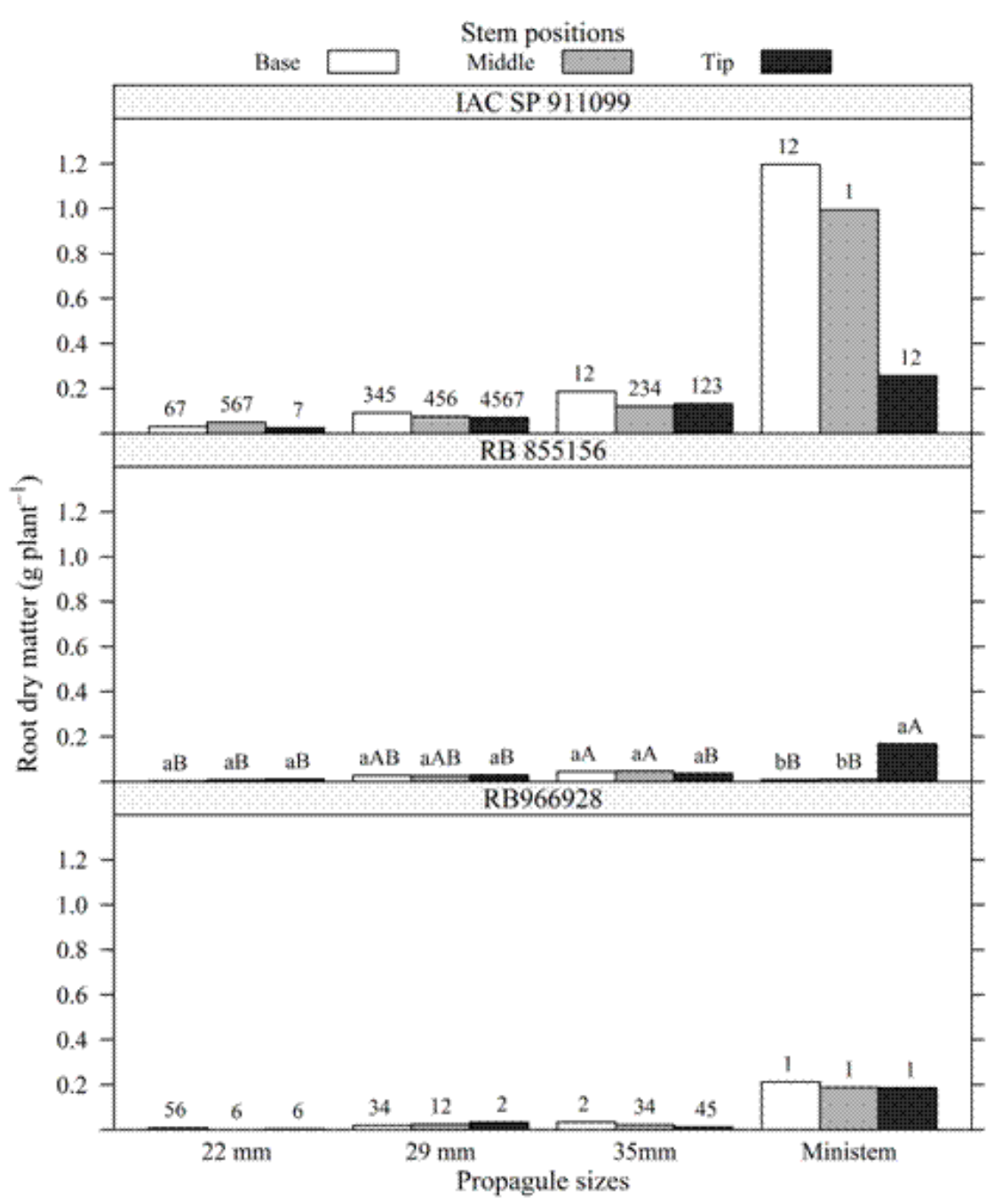

Figure 3 - Dry mass of the roots in the cultivars IACSP91-1099, RB855156 in the different positions of the stem and types of vegetative material (bud and mini-stem). (Means followed by the same lowercase letter do not differ by Tukey test $(p>0.05)$ between the positions of the stem for the same type of vegetative material; Means followed by the same uppercase letter do not differ by Tukey test $(p>0.05)$, it comparing the same position of the stem in each type of vegetative material; and Means followed by the same number do not differ by Friedman test $(p>0.05)$ between the position of the stem for the same type of vegetative material). 
According to the analysis of variance, for the variable height of cultivar IACSP91-1099, there was interaction between the different propagule sizes and stem positions. The greatest increase of height in sugarcane seedlings occurred in the mini-stem propagule size, at the tip position. The lowest seedling growth observed for this cultivar was for the propagule with size 1, at all stem positions. According to the results of the Friedman Test, cultivars RB855156 and RB966928 also showed interaction between the different propagule sizes and stem positions. Cultivar RB855156 showed the best plant height when the propagule size was the mini-stem, at the tip position, although not differing statistically from the propagule with size 3 , at the tip and middle positions. However, for cultivar RB966928, the best plant height was when the propagule size was the mini-stem, at all stem positions, differing significantly from the other treatments (Figure 4).

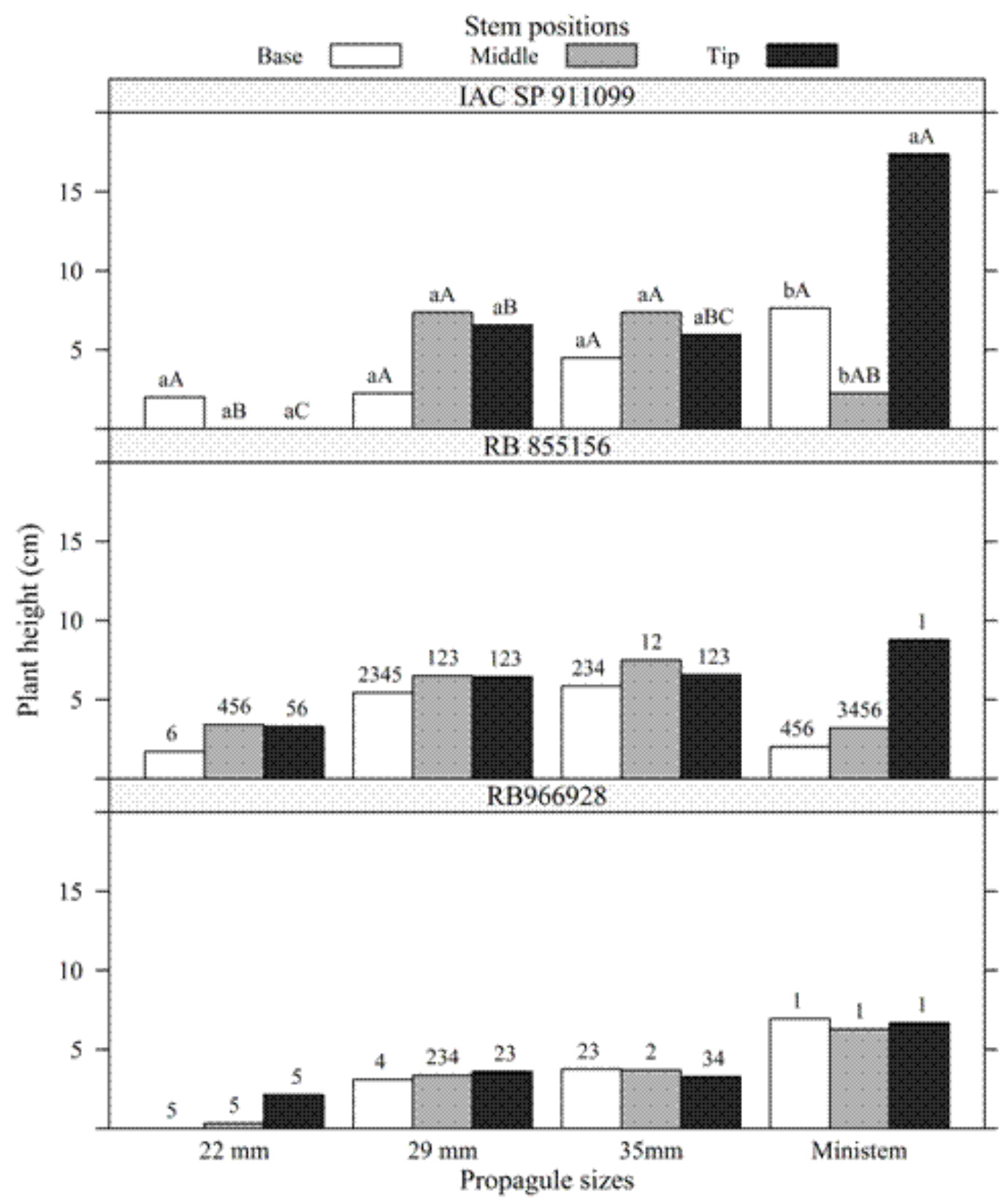

Figure 4 - Plant height of the cultivars IACSP91-1099, RB855156 and RB966928 originated from the different size of propagules $(22 \mathrm{~mm}, 29 \mathrm{~mm}$ e $35 \mathrm{~mm}$ ) and sugarcane stalks (Mini-stem). (Means followed by the same lowercase letter do not differ by Tukey test $(p>0.05)$ between the positions of the stem for the same type of vegetative material; Means followed by the same uppercase letter do not differ by Tukey test $(p>0.05)$, it comparing the same position of the stem in each type of vegetative material; and Means followed by the same number do not differ by Friedman test $(p>0.05)$ between the position of the stem for the same type of vegetative material). 


\section{Discussion}

The definition of the propagative material (bud) size and of the stem position, from which the sugarcane bud is removed, can contribute to improve the seedling production system. According to Silva et al. (2004), the amount of sucrose from the propagative material is directly related to the reserve material, being extremely important for germination or emergence. Shih and Gascho (1980) argued that during the first 30 days, when the supporting roots appear and buds sprout, the cane plant lives on the nutrient reserve of the stem. After this cycle, roots from the primary and secondary tillers grow, thus the supporting roots become unusable and the cane plant depends only on the activity of the roots from the tillers.

According to the emergence results found in this study, it can be seen that the amount of reserve of propagative material plays a major role in the emergence of plants. Sprouting is a biological process, which, like all others, consumes energy. This energy originates from the degradation of stem reserve substances through the breathing process, i.e., $\mathrm{O}_{2}$ molecules are required to "burn" these substances. In a period of about 60 days, stem reserves are fundamental for the evolution of the sprouting process. This dependence decreases as the root system develops, with a higher active surface of absorption of soil water and nutrients (Casagrande, 1991). The three evaluated cultivars are of early cycle, presenting a higher emergence rate compared to late cycle cultivars.

According to Carneiro et al. (1995), the organic and nitrogen reserve of the stem-seed is of direct importance for the sprouting and initial growth of the cane plant. Therefore, this reserve should be evaluated as one more factor that, combined with several others, may affect the final yield of sugarcane.

The bud with size 3 can be used in substitution of the mini-stem to optimize the process of production of sugarcane seedlings in a greenhouse, since seeders could be used instead of minitubes (places where pre-sprouted seedlings are usually germinated). According to the results found, the bud with size 3 had very good performance, inferior only to the mini-stem.

The increase of the shoot dry mass is associated with the greater development of roots and better absorption of nutrients (Medina et al., 2002). Civiero et al. (2016) studied the interaction of the effect of an amino acid and a humic substance with the size of the mini-stem in the initial development of sugarcane. The authors verified that, regardless of the application of the product, the use of one bud only showed a lower shoot dry mass than the use of mini-stem $(16 \mathrm{~cm})$.

When observing the performance of shoot compared to root growth, the results are consistent with the report by Malavolta and Haag (1964), who state that in some cultivars the roots develop before the shoots, while in other cultivars the reverse occurs. This can be verified in cultivars RB966928 and RB855156, which had greater shoot growth than culti- var IACSP91-1099. This latter cultivar, in turn, had better performance in root growth.

Civiero et al. (2016) verified that with the use of one bud only, total root length was $49.37 \mathrm{~cm}$, while for $16-\mathrm{cm}$ mini-stem, this value was $80.31 \mathrm{~cm}$, representing an increase of $41.5 \%$ in the root system. This higher shoot and root biomass production is probably related to the nitrogen content in the mini-stem.

As with the other variables evaluated, the best height was also verified in the mini-stem, probably due to the higher energy reserve found in this material. Carneiro et al. (1995) observed that the dry mass of mini-stems decreased with time, implying that the reserve of these mini-stems was used in the sprouting and initial growth of the cane plant. In other words, there must be an energy reserve for the initial growth of the cane plant, however, it does not have to be as large as possible. After its initial development, the plant uses other forms of nutrients, coming both from the soil and from fertilizers. Thus, the largest bud, which presented data close to that of the mini-stem, could be a viable alternative in the production of sugarcane seedlings.

According to the results of the variables presented in this work, the bud removed from the upper part (tip) of the stem was the one that presented the best performance. Aude (1993) states that the internodes that develop first accumulate sugar faster and contain higher levels of sucrose and mineral salts, while those of the apex contain higher levels of glucose, nitrogen and water. Bud sprouting is directly correlated with the content of glucose, nitrogen and water, thus sprouting will be faster in the mini-stems coming from the stem apex. Base buds, with high content of sucrose and mineral salts, need to convert sucrose to glucose. Therefore, these buds take longer to sprout.

\section{Conclusions}

The mini-stem and the $35 \mathrm{~mm}$ propagule taken from the tip of the stem are the best alternatives for the production of sugarcane seedlings.

\section{References}

Aude MI da S (1993) Growth stages of sugarcane and its effects on productivity. Ciência Rural 23(2):241-248.

Carneiro AEV, Trivelin PCO, Victoria R (1995) Utilização da reserva orgânica e de nitrogênio do tolete de plantio (colmo-semente) no desenvolvimento da cana-planta. Scientia Agricola 52(2):199-209.

\section{Casagrande AA (1991) Tópicos de morfologia e fisiologia da cana-de-açúcar. FUNEP, Jaboticabal.157p.}

CTC (2015) Centro de Tecnologia Canavieira. Etanol segunda geração. Disponível em <http://www.ctcanavieira.com.br/etanol2g.html>.

Acesso em 24 ago. 2017. 
Civiero JC, Fiori-Tutida AC, Daros E, Alves MJ, Figueiredo GG (2016) Initial growth of sugar cane due to mini-rebolo size of biostimulants application. Applied Research \& Agrotechnology 9(1):7-15.

CONAB (2017) Companhia Nacional de Abastecimento. Acompanhamento da safra brasileira cana-de-açúcar. Observatório Agrícola 3(4):82.

Dillewijn C van (1952) Botany of sugar cane. Waltham: Chronica Botanica, 371p.

Eggert H, Greaker M (2014) Promoting second generation biofuels: does the first generation pave the road?. Energies 7(7):4430-4445.

Landell MG de A, Campana MP, Figueiredo P (2012) Sistema de multiplicação de cana-de-açúcar com uso de mudas pré-brotadas (MPB), oriundas de gemas individualizadas. Instituto Agronômico, Campinas. Documentos IAC (109). 16p.

Leal MRL, Galdos MV, Scarpare FV, Seabra JE, Walter A, Oliveira CO (2013) Sugarcane straw availability, quality, recovery and energy use: a literature review. Biomass and Bioenergy 53:11-19.

Malavolta E, Haag NP (1964) Nutrição e adubação. In: Malavolta E (ed.) Cultura e adubação da cana-deaçúcar. Instituto Brasileiro da Potassa, São Paulo, p.237-278.
Maguire JD (1962) Speed of germination aid in selection and evaluation for seedling emergence and vigor. Crop Science 2(2):176-177.

Marin FR (2014) Eficiência de produção da cana-deaçúcar brasileira: estado atual e cenários futuros baseados em simulações multimodelos. Esalq (Tese de livre-docência).

Medina C de C, Fonseca I, Neves CSVJ (2002) Crescimento radicular e produtividade de cana-deaçúcar em função de doses de vinhaça em fertirrigação. Semina: Ciências Agrárias 23(2):179-184.

Segato SV, Mattiuz CFM, Mozambani AE (2006) Aspectos fenológicos da cana-de-açúcar. In: Segato SV, Pinto AS, Jendiroba E, Nóbrega JCM (ed.) Atualização em produção de cana-de-açúcar. Livroceres, Piracicaba, p.19-36.

Shih SF, Gascho GJ (1980) Relationships among stalk length, leaf area, and dry biomass of sugarcane 1. Agronomy Journal 72(2):309-313.

Silva MA, Carlin SD, Perecin D (2004) Fatores que afetam a brotação inicial da cana-de-açúcar. Revista Ceres 51(296):457-466. 